\title{
Infection-Genomics of COVID-19: Are some communities resistant?
}

\author{
R. Manjunatha Kini ${ }^{1,2}$ and Swati Kundu ${ }^{1}$ \\ ${ }^{1}$ Department of Biological Sciences, Faculty of Science, National University of Singapore, 117558, \\ Singapore \\ 2Department of Pharmacology, Yong Loo Lin School of Medicine, National University of Singapore, \\ 117600 , Singapore \\ *Corresponding author. Email: dbskinim@nus.edu.sg
}

\begin{abstract}
The 2019-Novel Coronavirus has currently gripped the world in terror, affecting 210 countries and territories as of April 29, 2020. Originating from Wuhan, Hubei province, China, the virus has spread so rapidly throughout the world and has already claimed 218,000 lives and is currently afflicting 3.14 million people. The US has over 1.03 million confirmed cases of COVID-19, followed by Spain, Italy, France, UK, Germany, Turkey, Russia, Iran, and China. On careful inspection of the COVID-19 statistics, a peculiar unsettling trend becomes apparent. Western European countries and the US appear to have difficulties in overcoming the catastrophe. In contrast, countries in East Asia, Middle East and mid-Europe have sorted out the situation. Here, we will highlight this trend and propose the importance of infectiongenomics (sankramikogenomics), in understanding the susceptibility to COVID-19 and the severity of disease progress. More detailed evaluation may also identify more susceptible populations. Such differences are due to variations in structure or tissue-specific expression (alternate splicing and accessibility) of the target receptors. So, we will highlight mere 12-fold lower affinity is insufficient to ignore CD147, as interactions occur between tens of spike proteins and equal number of cell surface ACE2 and/or CD147. Similar to pharmacogenomics to drug development and precision medicine, Sankramikogenomics will become an important field in other infectious diseases and pathogenicity.
\end{abstract}

\section{Introduction}

Currently, the whole world is put on hold by a novel corona virus, SARS-CoV2, that is closely related to the Severe Acute Respiratory Syndrome (SARS) virus that caused havoc in 2013 (Wu F et al., 2020). Coronavirus disease (COVID-19) started by the end of 2019 in China and 
spread in many Asian countries by February 2020. By end of March, COVID-19 infected 200 countries, claimed $\sim 30,000$ lives and afflicted over 450,000 people. Within the last two weeks, it has spread to 2.1 million people and claimed 134,600 lives. In many parts of the world, COVID-19 is still marching through the communities unabated.

Over the last several decades, several infectious diseases have emerged to infect the mankind. These diseases, depending on their severity, caused serious disruptions to either a small region of the world or spread throughout the world with significant number of human deaths and devastation. In 2018, malaria infected 228 million people worldwide claiming 405,000 lives. African Region had a disproportionately high share of $93 \%$ of malaria cases and $94 \%$ of malaria deaths (World Malaria Report, 2019). Nearly all malaria deaths are caused by Plasmodium falciparum, the deadliest malaria parasite. P. falciparum accounted for $99.7 \%$ of cases in the African Region, while other regions are affected by less virulent species (World Malaria Report 2008). In contrast, $70 \%$ dengue infection burden is in Asia, although 129 countries are at risk (Bhatt et al., 2013). Similarly, seasonal influenza, avian flu and other air borne diseases also affect certain regions of the world but has little or no impact elsewhere. With these factors in mind, we evaluated COVID-19 disease data.

The COVID-19 infection data (https://www.worldometers.info/coronavirus/) shows the total number of confirmed cases in each country along with Active cases and Closed cases defining patients still undergoing medical treatment or the cases closed as the patients have either recovered or died. These 'Closed cases' could be considered as the completion of the battle between COVID-19 and us with two outcomes - discharge from the hospital or death. From these data, one can calculate the interim death rate (IDR); IDR is the percent of cases ending in death among all 'Closed cases' at any given time. IDR is distinct from case fatality rate that can be evaluated after the complete resolution of COVID-19. The IDR data will alert all relevant government agencies, clinical institutions, pharma industry as well as common man regarding COVID-19 outcome.

Here, we have used IDRs to understand the impact of COVID-19 in various countries and regions in the world. The data suggests that, as with any of the vector- or air-borne infectious diseases, COVID-19 also shows differential impact on various regions of the world. We, therefore, propose to evaluate infection-genomics (sankramikogenomics), in understanding the susceptibility to COVID-19 and the severity of disease progress.

\section{Disease statistics and methods}


All COVID-19 data were obtained from https://www.worldometers.info/coronavirus/ Worldometer website. As the data is dynamic and changes rapidly, we have used the latest data obtained on April 17, 2020, 8 am (Singapore time). The IDR (\%) was calculated as follows:

$$
\text { IDR }=\frac{\text { Number of deaths }}{\text { Total closed cases }} \times 100
$$

We also calculated Recovered case (\%) and Closed case (\%) as follows:

$$
\text { Recovered case }(\%)=\frac{\text { Number of recovered cases }}{\text { Total number of cases }} \times 100
$$

$$
\text { Closed case }(\%)=\frac{\text { Number of closed cases }}{\text { Total number of cases }} \times 100
$$

\section{Results and Discussion}

In the first wave, COVID-19 infections started in and affected mostly China. Then people in surrounding East Asian countries were infected. In the second wave, these infections affected Middle East countries, particularly Iran was most affected. In the third wave, COVID-19 infections affected Western European countries and the US. In the fourth and final wave, it has spread to remaining parts of the world. There is no clear separation or breaks between these waves. These waves are considered only to keep the discussions simple.

\section{The first wave of COVID-19}

COVID-19 in Eastern Asian countries: The first COVID-19 infection in China is thought to be on November 17, 2019, it was first identified as the disease caused by a new coronavirus by Zhang Jixian on December 27, 2019 (Ma, 2020). The first death was recorded on January 9 and on January 22 had 571 total confirmed cases, 554 active cases and all 17 closed cases ended in death, 100\% IDR (Figure 1). This is understandable considering the doctors and paramedical people were not fully aware of the symptoms as they were witnessing nature's new drama unfold. By January 31, total confirmed cases increased to 11,791 but there were 502 resolved cases including 259 death and 243 recovered. With this the IDR plummeted to $51.5 \%$. By February 10, there were 42,638 confirmed cases with 5012 resolved cases and 20.2\% IDR. By 
February 15, within 24 days, they cut to the IDR to 15\%. All these reductions in IDRs were during the upswing of COVID-19 infections. Currently, with $99.22 \%$ out of 82,858 cases resolved, the IDR is decreased to $5.64 \%$ (Table 1). About $80 \%$ of deaths were in patients older than 60 years, and $75 \%$ patients had pre-existing health conditions including cardiovascular diseases and diabetes. China to a great extent has overcome COVID-19 infections. Although there are a small number of cases trickling in daily, they probably have blunted the peak impact through lockdown and other drastic measures. The data suggest that the clinical institutions and the government with people's cooperation, restricted the COVID-19 related IDR (Table $1)$.

In South Korea, the first case was recorded on January 20, 2020. The IDR reached the peak of $51.5 \%$ (32 deaths) on March 3 and since then declined to 24.1\% on March 6 on much improved recovery (Figure 2). With aggressive measures, they controlled the spread without shutting everything down through testing most of the population(Beaubien, 2020) and reduced the IDR to current rate of $2.68 \%$ (Table 1). Similarly, by adopting different measures Singapore (daily monitoring of temperature and symptoms, quarantine and stay-home-notice, contact tracing, business continuity plan, social distancing and work from home) and Hong Kong reined COVID-19 infections and IDRs (1.23\% and 0.49\%, respectively). Japan (investigating flareups of cases, identifying the infected and then monitoring their contacts) also controlled COVID-19 infection and IDR (Table 1). Taiwan, Thailand, Vietnam and Malaysia also have IDRs range between 0 to $2.42 \%$ except for Japan (17.18\%) (Table 1). The battle-readiness was enhanced probably through the experience gained from SARS-2013 and MERV-2015 infections that swept this region. Thus, most of the East Asian countries, in many ways able to control COVID-19 infections and death (Figure 2).

\section{The second wave of COVID-19}

COVID-19 in Middle East countries: This wave started in Iran on February 19 with two COVID-19 infections and showed steady increase until March 30 to reach 44,605 infections. From March 30 onwards, they cut the number of infections in half from 3200 to 1500 on April 15. From March 16 to April 11, Iran had 125 or more COVID-19 deaths and the death rate is also slowly coming down. Currently, with $84.59 \%$ out of 92,584 cases resolved, the IDR is decreased to $7.50 \%$ (Table 2). All 11 Middle East countries have low IDRs ranging between 0.61-7.50\% with Bahrain at the lowest IDR. Thus, despite more than 162,000 COVID-19 
infections, Middle East countries have done extremely well in their fight against COVID-19 (Figure 2).

\section{Alarming IDRs in the first world}

COVID-19 in Western European countries: In contrast, COVID-19 has left a significant track of death and devastation in many Western European countries (Table 3). On January 31, France and Germany had 6 and 7 COVID-19 cases, respectively, lower than Japan (15), Singapore (13) and South Korea (11) cases (Wu Z and McGoogan, 2020). On February 15, Germany, Italy, Spain and UK had 16, 3, 2 and 9 cases, compared with Japan (259), Singapore (65) and South Korea (28) cases. Then, something changed - confirmed COVID-19 cases increased to almost uncontrolled proportions in the coming weeks in Germany, Italy, Spain and UK; even after 49 days the number of confirmed cases is increasing $\sim 8 \%-14 \%$ each day compared to the previous day. What is more worrisome is that the IDRs in many European countries are alarmingly high. The UK tops the chart with $98.44 \%$ IDR followed by Netherlands, Norway, Sweden, Portugal, Belgium, France and Italy (all above 28\%; Table 3). Some of these initial high IDRs were due to herd-immunity approach in solving COVID-19 (Kwok et al., 2020). In stark contrast, Germany, Switzerland and Austria have low IDRs (4.33-6.99\%) (Table 3). Iceland has the lowest IDR of $0.61 \%$. Thus, most Western European countries were exposed to very severe outcomes with COVID-19 infections. Only a small number of countries have regained control over COVID-19 (Figure 3).

COVID-19 in the US: On February 15, the US had 15 cases, the number reached 100 cases on March 2 and 6,346 cases on March 17. COVID-19 cases swell 100-times to 677,056 in about a month (Figure 1). Since April 2, the number is increasing 30,000 new cases on an average every day. We evaluated the data from all 50 US states (Table 4). Nineteen states have been successfully defending the infections keeping the IDRs below 10\%. South Dakota with IDR $(1.12 \%)$ leads the country, followed by Wyoming, Hawaii, Tennessee, Alaska, Montana, North Dakota, Arkansas, Utah, South Carolina, Idaho, Texas, Iowa, New Hampshire, West Virginia, Nevada, Maine, Oklahoma and Louisiana (Table 4). These states have done extremely well in fighting COVID-19 infections and related deaths. Next four states, Delaware, Wisconsin, New Mexico, and Minnesota have IDRs range between 11.11 and 13.60\%, immediately followed by five states with IDRs below $25 \%$. These nine states have done well in avoiding extreme impact of COVID-19 infections. The next eight states have IDR range from $25-50 \%$. Unfortunately, 15 states have poor record in fighting COVID-19. They are grouped states into 
one with 51-79\% IDRs and the other above 80\% IDRs (Table 4). These 23 states, particularly the last 10, need substantial measures to slow down the devastations caused by COVID-19.

\section{Angiotensin-converting enzyme 2 (ACE2), ACE1 and COVID-19}

The novel coronavirus causing COVID-19 is closely related to SARS virus (Wu F et al., 2020) and binds to host receptor angiotensin-converting enzyme 2 (ACE2) through its spike protein receptor-binding domain (RBD) to gain entry into the cell (Lu F et al., 2020; Wan et al., 2020; Wrapp et al., 2020). ACE2 was identified as a Captopril-insensitive homolog of ACE1 (Tipnis et al., 2000). This paralog converts angiotensin II to angiotensin 1-9 (Donoghue et al., 2000). ACE2 removes one amino acid residue, while ACE1 is a carboxydipeptidase and removes dipeptides from the C-terminal from various peptide substrates. Further, classical ACE inhibitors do not inhibit ACE2 activity. ACE1 inhibitors that prevent the conversion of angiotensin I into angiotensin II, and angiotensin II receptor antagonists reduce cardiac fibrosis, left ventricular enlargement and remodelling (Re, 2004). Hence, ACE1 contributes to the development of cardiovascular disease through the generation of angiotensin II. In contrast, ACE2 plays a cardioprotective role and eliminates many of the negative consequences of angiotensin II (For details, see Ussher and Lopaschuk, 2012; Turner, 2015). Thus, primarily ACE2 acts as a counterbalance to ACE1.

Tissue-specific expression of ACE2 and associated proteases: After the completion of human genome project, there have been a number of efforts to systematically annotate the proteincoding parts and to identify their tissue specific expression. Using quantitative transcriptomics analyses combined with antibody-based profiling, Fagerberg et al. (2014) created a comprehensive, integrative expression map of 27 major organs and tissues. Accordingly, highest expression of ACE2 (average FPKM in parentheses) occurs in small intestine (93.7), followed by duodenum (69), gall bladder (32.6), kidney (30.8), testes (26.9) and heart (12.3). Interestingly, the main target of SARS-CoV2, the lung has extremely low expression ( 0.3 from 5 samples). In contrast, ACE1 is highly expressed in the lung (32.6) (Table S1). Human proteome data also suggests ACE1 is expressed in the adult lung but ACE2 is not (Kim et al., 2014; Wilhelm et al., 2014; Schmidt et al., 2018). Single cell RNA-seq data also suggests that ACE2 is expressed in a small number (1-2\%) of type II alveolar cells (AT2) of the lungs (Zou et al., 2020). Similarly, almost no nasal and bronchial cells express high levels of ACE2. However, the epithelial cells from the respiratory track has $2 \%$ ACE2 positive cells (Zou et al., 2020). Single cell RNA-seq data indeed suggests the expression of ACE2 in myocardial 
cells (heart, 7.5\%), proximal tubule cells (kidney, 4\%), urothelial cells (urinary bladder, 2.4\%), digestive track epithelial cells (esophagus, $>1 \%$; and ileum, $\sim 30 \%$ ), and make them vulnerable to this infection (Zou et al., 2020). Recent immunohistochemistry studies of 24 human tissues showed that highest ACE2 expression was in microvilli of the intestinal tract and renal proximal tubules, in membranes of gall bladder epithelium, testicular Sertoli cells and Leydig cells, a subset of glandular cells in seminal vesicle, and in cytoplasm cardiomyocytes (Hikmet et al., 2020). ACE2 protein expression was not detected in lung, bronchus, nasopharynx, esophagus, stomach, endometrium, smooth muscle tissue, spleen, cerebral cortex, adipose tissue or different structures of the skin. Based on these findings, the authors questioned the role of ACE2 for infection of human lungs (Hikmet et al., 2020). In immunostaining techniques, it is difficult to identify $1 \%$ cells (finding one cell in a hundred) that express ACE2, particularly when the expression levels are not astronomically high. Such limitation can be overcome by robust single-cell RNA-seq data. Single-cell RNA-seq studies in 13 tissues showed that ACE2 is expressed in lung AT2, liver cholangiocyte, colon colonocytes, esophagus keratinocytes, ileum endothelial cells, rectum endothelial cells, stomach epithelial cells, and kidney proximal tubules (Qi et al., 2020). Lukassen et al. investigated the expression of ACE2 and the transmembrane protease serine 2 (TMPRSS2; thought to play important role in infection (Hoffman et al., 2020)) in lung tissue and in cells derived from subsegmental bronchial branches (Lukassen et al., 2020). Their data suggest that ACE2 as well as TMPRSS2 are predominantly expressed in a transient secretory cell type in the subsegmental bronchial branches. These cells show an enrichment for pathways related to RHO GTPase function and viral processes suggesting their increased vulnerability for infection (Lukassen et al., 2020). ACE2 and TMPRSS2 are co-expressed in nasal epithelial cells, specifically goblet and ciliated cells (Sungnak et al., 2020). Muus et al. provide the most comprehensive and integrated analyses of cell type-specific expression of mediators of SARS-CoV-2 viral entry - ACE2, TMPRSS2 and Cathepsin L (CTSL) (Muus et al., 2020). As expected, secretory goblet and multiciliated cells in the proximal airways and AT2 cells in the distal lung are ACE2 ${ }^{+}$TMPRSS2 $^{+}$dual-positive cells. In addition, enterocytes, pancreatic ductal cells, prostate luminal epithelial cells, cholangiocytes, oligodendrocytes in the brain, inhibitory enteric neurons, and fibroblasts and pericytes from heart and other tissues are also dual-positive $\left(\mathrm{ACE}^{+} \mathrm{TMPRSS}^{+}\right)$. Among them, such cells are most prevalent in ileum followed by liver, lung, nasal mucosa, bladder, testis, prostate and kidney (Muus et al., 2020). Single-cell assay for transposase-accessible chromatin sequencing (Chen et al., 2018) data indicates that chromatin at both the ACE2 and TMPRSS2 loci are accessible in epithelial cells, especially 
AT2 cells (Muus et al., 2020). Further, $\mathrm{ACE}^{+} \mathrm{CTSL}^{+}$cells are found in the olfactory epithelium, ventricular cardiomyocytes, heart macrophages, and pericytes in multiple tissues, including the heart, lung, and kidney. In addition, several other proteases have been shown to be co-expressed with ACE2 and they may play a role in COVID-19 infections (Muus et al., 2020). The epithelial cells of the oral mucosa and tongue (Xu et al., 2020) and cornea and conjunctiva (Xia et al., 2020) have high ACE2 expression.

ACE2, a gateway in COVID-19 infections: SARS-CoV2 enters an individual through the ACE2 receptors found in the respiratory track (Muus et al., 2020 and several other references). Nature has a number of physical barriers to protect us from such infections including nose hairs, curved and mucous protected nasal passages, and ciliated mucous membrane. These barriers provide excellent protection considering an average adult breathes 11,000 liters of air/day. Despite the number of particles, viruses and bacteria among other pathogens that enter our system daily, most of us remain healthy unaffected by the plethora of "attacks". Most of these living or dead particles are trapped in the mucus and slowly pushed out of the nose or mouth through cilia, the microscopic hairs. About 1.4 liters of mucus/day keeps the nasal cavity and airways moist, and "captures" all particulate matter for disposal. Mucus gets diluted with serous fluid and swallowed twice a minute. When an individual is dehydrated due to low water intake, cold and dry winters, air conditioners/ heaters or smoking, the volume of serous fluid is reduced. This in turn leads to thick and sticky mucus, which makes people more susceptible to illness, allergies and other respiratory problems (D'Amato et al., 2018). Such dry nasal and upper respiratory track provide SARS-CoV2 access to epithelial cells and their ACE2 resulting in potential infection. Thus, preventing dehydration by ample water intake will reduce the transmission.

Alternatively, the virus could enter through mouth and eyes as the epithelial cells of the oral mucosa and tongue (Xu et al., 2020) and cornea and conjunctiva (Xia et al., 2020) also have high ACE2 expression. Entry or secondary site infection through the mouth probably leads to frequent olfactory and taste disorders in the patients before the onset of full-blown disease (Giacomelli et al., 2020). These routes are accessible through frequent touching of the face and rubbing of eyes. Surprisingly, individuals touch their face 23 times/hour (Kwok et al., 2015). Among these face touches, $44 \%$ contact with a mucous membrane (mouth, nose and eyes, one third times each), whereas $56 \%$ contact nonmucosal areas. Thus, hand hygiene is an essential and inexpensive preventive method to break transmission associated with self-inoculation. 
Key covariates associated with COVID-19 severity: The clinical consequences of COVID-19 infection ranges from asymptomatic carrier status to death. Three key covariates, age, sex and smoking, define COVID-19 severity. The initial evaluation indicates that the disease severity and mortality rates show a significant rise with age $(<0.1 \%$ for patients under 30 years old to $>10 \%$ for patients over 70) (Wang et al., 2020; Hauser et al., 2020). Children are less likely to develop severe disease compared to adults ( $\mathrm{Lu} \mathrm{X}$ et al., 2020). There is also a slightly higher incidence and mortality in men compared to women (del Rio and Malani, 2020; Guan et al., 2020). Earlier studies using bulk transcriptomics and analysis of single-cell RNA-seq data failed to find significant differences between age groups ( $>60 \mathrm{vs}<60$ ) or gender groups (male vs female) (Cai G., 2020). Muus et al. correlated ACE2 expression in double positive ACE2 ${ }^{+} \mathrm{TMPRSS}^{+}$cells such as airway epithelial cells (basal, multiciliated, and secretory cells), alveolar AT2 cells, and submucosal gland secretory cells (Muus et al., 2020). The expression of ACE2 increases with age in basal and multiciliated cells, while it is elevated in males in airway secretory cells and AT2 cells.

Preliminary analyses indicate that more adverse events occur in smokers (Vardavas and Nikitara, 2020). Interestingly, ACE2 gene expression in Asian current smokers is higher compared to non-smokers but not in Caucasian current smokers (Cai, G., 2020). ACE2 is expressed in remodelled AT2 cells of former smokers and in goblet cells and club cells of current smokers and non-smokers, respectively. Thus, smokers especially former smokers may be more susceptible to SARS-CoV2 (Cai, G., 2020). The sex predisposition may be due to the much higher smoking rate in men than in women in China (Cai, H., 2020). ACE2 expression in multiciliated cells is elevated in former or current smokers (Muus et al., 2020). Further, in AT2 cells, there is joint up-regulation of ACE2 and TMPRSS2 with age and ACE2 and CTSL down-regulation in smokers. Overall, there is increased ACE2 expression in airway epithelial cells and reduced expression in AT2 cells of smokers. In the mouse model data also suggested the increased expression levels of ACE2 in airway secretory cells, but not in AT2 cells (For details, see Muus et al., 2020). Thus, expression of ACE2 and associated proteases support the impact of covariates on COVID-19 severity.

\section{CD147, the other receptor, may be as important as ACE2}

Recently, a second receptor for SARS-CoV2, namely CD147 (also known as Basigin or EMMPRIN) was identified to play important role in COVID-19 infection (Wang et al., 2020). It is a transmembrane protein of the immunoglobulin super family and is the main upstream 
stimulator of matrix metalloproteinases. CD147 may be upregulated during asthmatic and diabetic complications. CD147 acts as receptor for the invasion on red blood cells by Malaria parasite Plasmodium falciparum (Muramatsu, 2012). Azithromycin, a classical antibiotic, prevents this invasion and used as a prophylactic against Malaria (Kain et al., 2001). It also exhibits anti-viral responses in epithelial cells through increased levels of interferons and interferon-stimulated proteins leading to decreased viral replication and virus release (Gielen et al., 2010; Tran et al., 2019). According to anecdotal reports, azithromycin in combination with hydroxychloroquine or chloroquine is used for treatment of COVID-19 (Damle et al., 2020). Hydroxychloroquine and chloroquine also exhibit direct in vitro antiviral activity (Liu et al., 2020). The open-label non-randomized clinical trial suggested the use of azithromycin and hydroxychloroquine for COVID-19 therapy (Gautret et al., 2020). In this trial, 26 patients treated daily with hydroxychloroquine $(600 \mathrm{mg})$ show a significant decrease in viral load after six days compared to untreated controls. Among them, all six patients who received azithromycin (500 $\mathrm{mg}$ on the first day followed by $250 \mathrm{mg}$ daily) show negative PCR results in nasopharyngeal samples. In comparison, $57.1 \%$ patients treated with hydroxychloroquine only, and $12.5 \%$ of untreated individuals were virus-free (Gautret et al., 2020). Although further clinical studies are essential to validate these findings, it appears that CD147 could be a target for COVID-19 treatment (Ulrich and Pillat, 2020).

Most studies suggest that the severe devastation due to directly related to two key structural features of SARS-CoV2; its increased affinity and enhanced protease access. The changes in the receptor binding domain (RBD) of spike protein leads to increased binding affinity to ACE2 compared to SARS virus (Wrapp et al., 2020; Walls et al., 2020). Further, insertion of "RRAR" furin recognition site (with improved host protease processing (Hoffmann et al., 2020; Walls et al., 2020)) may make it more virulent, akin to avian and human influenza viruses (Chen et al., 1998). The binding affinity of the spike protein to CD147 is weak ( $\mathrm{Kd}, 0.185 \mu \mathrm{M}$ compared to human ACE2, $15 \mathrm{nM}$ ) (Wang et al., 2020). Although the affinity difference between individual molecules of spike protein and the two target receptors are $\sim 12$-fold, it may not have a significant impact on the interaction between the virus particles and the target cell. These affinities are determined by the surface density and accessibility of these receptors to the virus particles. Each virus particle binds to several ACE2 and/or CD147 receptor molecules on the surface of the target cell through multiple spike proteins, similar to hooks and loops in a Velcro strip. Thus, not only individual affinities but also how many such interactions contribute together to binding determines the overall effectiveness of the interaction. Time and again we 
have seen how low affinity binding interactions in biology leads to high affinity, precision binding (For example, see Crocker et al., 2015). Considering such cooperative binding interactions, we propose that CD147 is also an important receptor to be considered in our war on COVID-19 infections. It may help us resolve some of the symptoms or complications observed during the disease.

\section{Infection-genomics (Sankramikogenomics)}

It is difficult to imagine or comprehend such high IDRs in most of the European countries and the US with optimal numbers of doctors, top class expertise and facilities. The knowledge and experience in handling COVID-19 or similar catastrophes may not be the key limiting factor. The total number of cases are yet to reach the total capacity of their healthcare systems, although some cities, such as New York, may have. It is also hard to believe that the high IDRs are due to old age and confounding comorbidity such as, cardiovascular disease, diabetes, chronic respiratory disease, hypertension, and cancer (Wu F and McGoogan, 2020; Guan et al., 2020; Yang et al., 2020). Therefore, we hypothesize that additional factors contributing to high IDRs could be (a) delay in seeking medical help and/or (b) susceptibility of patients of certain ethnicities. The delay in reaching clinics and hospitals could be due to milder, apparently 'innocuous' symptoms associated with the early stages of COVID-19 infection. The lack of proper medical insurance cover, particularly in the US, may prevent some patients from seeking medical help in a timely fashion. However, this may not be a concern in Europe where most countries have accessible healthcare systems.

Some communities appear to be resistant to COVID-19 infection and severity: It is also important to evaluate the human receptor and associated factors to complete the picture of this present pandemic. Considering all things and circumstances are equal, which they are not, three distinct groups of countries have been able to control COVID-19 calamity. They are (a) Germany, Austria and Switzerland in Western Europe (Figure 3), (b) East Asian countries (Figure 2), and (b) Middle East countries (Figure 2). They have been successful in defending against the COVID-19 catastrophe with low IDRs (Tables 1-3). Without trying to take the credit away from the medical and paramedical services and their innovative methods as well as the efforts of their government and the community, and putting 'political correctness' aside, we considered the demographic ethnicity of these countries. Germany has $87.2 \%$ of the population belonging to German ethnicity (2017 estimate), while more than $70 \%$ of the populations of Austria and Switzerland are closely related to Germanic lineage 
(https://www.indexmundi.com/COUNTRY/demographics_profile.html). Interestingly, the 'first four German patients' who were positively confirmed to have the virus recovered from COVID-19 without hospitalization (Rothe et al., 2020). Taking these and other factors into account, we propose the possibility that people of this ethnic background may be 'somewhat resistant' to COVID-19. To test this hypothesis, we considered the demographic ethnicities, with specific focus on ancestral history and percent of Germans, of various US states with low and high IDRs. Of the 25 US states with low IDRs have six-out-of-seven states have high proportion of population belonging to German ethnicity; South Dakota (38.8\%), North Dakota (41.4\%), Iowa (35.1\%), Wisconsin (40.5\%), Minnesota (33.8\%) and Kansas (27.2\%) (Table 4). Only Nebraska (36.1\%) has high IDR and is in the bottom 13th position. Hawaii, although has only $5.9 \%$ population belonging to German ethnicity, shows low IDR of $1.84 \%$. The low IDR could be due to its $19.2 \%$ East Asian population (the highest among the US states) (see discussions below). In contrast, 6-out-of-10 states that have less than $11 \%$ German population have high IDRs (>80\%). Although it is crystal clear that COVID-19 infections and outcomes depend on innumerable factors including (but not limited to) population density, healthcare facility and personnel, access to healthcare insurance, and total COVID-19 infections and capacity, we observed that large number of the states follow the 'German factor'.

As the first country to face the unknown enemy, only China had an explosion of COVID-19 infections (Figure 1). The high rate of infection was also due to unexpected viral transmission by asymptomatic patients through their natural day-to-day interactions. Despite this initial onslaught, China along with eight countries including South Korea, Hong Kong, Japan and Singapore reined COVID-19-associated death and devastation compared to the rest of the world (Table 1). In addition to enforced social discipline and other measures, it is also possible that there could be an 'Oriental factor' responsible for the resistance factor. Hawaii has high proportion of Oriental Asian population and low IDR (discussed above) (Table 4).

COVID-19 infections were also rapidly brought under control in Middle East countries; they have an average of $41.1 \%$ Closed cases with low IDRs (Table 2). The people from this region are of distinct ethnicity than both German and Oriental people. Therefore, we propose the third "Middle East factor" that reduces the severity of COVID-19 infections. Thus, the differential susceptibilities are probably due to three distinct factors identified here. Further, detailed studies will expose additional 'resistance' and/or 'susceptible' factors responsible for determining the impact of COVID-19 infections on people from different ethnic backgrounds. With more interracial (or inter-ethnic) marriages, these distinguishing features will be blurred 
with time. The search and identification of such differences between people belonging to distinct ethnicities could be related to structure, splice forms and expression regulation of ACE2 and other associated genes; we propose to name such studies as Infection-genomics of COVID-19. We would like to coin the term "Sankramikogenomics" for such susceptibility/resistance studies of other infectious diseases. In the Indian language Hindi, the word "Sankramik" means infections. Sankramikogenomics is conceptually similar to pharmacogenomics where we identify genes that affect an individual's response to drugs and avoids "one size fits all" concept with a move towards precision medicine. As three resistance phenotypes have evolved independently, a common mechanism may not be able to explain the resistance in these three distinct communities. Pharmacogenomics helps us to understand how the genetic makeup of an individual affects his/her response to drugs and paves way to precision medicine. Sankramikogenomics, on the flip side, helps us to understand how the genetic makeup of an individual affects his/her response (susceptibility, resistance and altered symptoms) to pathogenic infections and severity of the diseases.

\section{ACE2 expression and vulnerability}

ACE2 the target receptor, which plays a crucial role in the entry of virus into the cell, has been the focus for the Infection-genomics of COVID-19 infection and disease progress. Several groups have analyzed human genome and single-cell RNA-seq databases for ACE2 variants, allele frequency and expression in various tissues to understand the susceptibility and mechanism of pathophysiology of COVID-19 infection (Cao et al., 2020; Delanghe et al., 2020; Zhao et al., 2020; Zou et al., 2020). In a recent study, Asian male (55 y) was reported to have an extremely large number of ACE2-expressing cell clusters, including type II alveolar cells (AT2), in the lung compared to five African American and two white individuals (Zhao et al., 2020). Single cell RNA-seq data with significant depth could be used evaluate ACE2 and CD147 expression along with relevant proteases and other accessory proteins in specific cell types of major organs will help us clarify details (Muus et al., 2020). Analyses of coding-region variants in ACE2 and the expression quantitative trait loci (eQTL) variants among different populations show that none of the ACE2 mutants are resistant to binding to the virus (Cao et al., 2020). Variations in allele frequencies in the eQTL variants along with varied ACE2 expression may suggest distinct susceptibility from different populations (Cao et al., 2020). The deletion/insertion (D/I) polymorphism in intron 16 of ACE1 shows geographical and ethnic variations (Oliveira-Paula et al., 2019) and the D allele is associated with a reduced ACE2 expression. D-allele frequency is inversely proportional to COVID-19 infections 
(Delanghe et al., 2020). Viruses will reach heart, kidney and ileum through blood, most likely at later stages, which is the leading cause of death through comorbidities. Patients with preexisting hypertension and cardiovascular diseases, particularly who are taking ACE inhibitors or angiotensin II receptor antagonists and have increased ACE2 expression (Ferrario et al., 2005; Huang et al., 2010), have an increased risk of severe disease and death (Driggin et al., 2020; Zheng et al., 2020). Thus, ACE2 is critical for initial infection followed by disease progression.

\section{ACE2 structure and vulnerability}

Minor sequence changes in ACE2 may alter the interaction between SARS-Cov2 virus with human cells and thus, the entry of the virus and infectivity. In a recent study, Stawiski et al. analyzed the polymorphisms of ACE2 with specific emphasis on its interaction with Spike protein. The authors analyzed large datasets (over 290,000 samples representing $>400$ population groups) and identified nine and 17 rare ACE2 variants that probably increase or decrease binding to virus spike protein (Stawiski et al., 2020). Such variations in ACE2, the target receptor that plays a crucial role in the entry of virus, probably explains the varied sankramikogenomics of COVID-19 in distinct ethnic people.

\section{Conclusions and future prospects}

CoVID-19 disrupted the most sophisticated systems and brought them to their knees. The unusual high IDRs in the US and major Western European countries compared to East Asian and Middle East countries could be due to differential susceptibilities of people belonging to distinct ethnicities. We hypothesized that Germanic, oriental and Middle East people may have enhanced resistance to COVID-19-induced death. These factors could be related to structure, splice forms and expression regulation of ACE2 and CD147 receptors or secondary mechanisms leading to death through comorbidities. We have initiated the search for such factors through sankramikogenomics. These mechanistic studies will help in developing strategies to reduce COVID-induced mortality. We urgently need to find therapeutic solutions to resolve this coronavirus gauntlet (Li and De Clercq, 2020; Rayner et al., 2020). These approaches along with better recovery protocols used in the some of the key healthcare centers will help reduce the death. COVID-19 is our warning siren; a strong cooperative, multi-pronged approach is needed overcome this catastrophe.

\section{Acknowledgments}


We thank Cho Yeow Koh and Rohan Bendre for initial analyses and critical discussions during the preparation of the manuscript. We thank Prakash Kumar for discussions during writing. This work was funded by the Tier-3 grant from the Ministry of Education, Singapore (MOE 2015-T3-1-003). 


\section{References:}

Beaubien J, 2020. How South Korea Reined In The Outbreak Without Shutting Everything Down. NPR News

Bhatt S, Gething PW, Brady OJ, Messina JP, Farlow AW, Moyes CL, Drake JM, Brownstein JS, Hoen AG, Sankoh O, Myers MF. "The global distribution and burden of dengue." Nature 496, no. 7446 (2013): 504-507. Doi: https://doi.org/10.1038/nature12060

Cai G. "Bulk and single-cell transcriptomics identify tobacco-use disparity in lung gene expression of ACE2, the receptor of 2019-nCov." MedRxiv (2020). Doi: https://doi.org/10.1101/2020.02.05.20020107

Cai H. "Sex difference and smoking predisposition in patients with COVID-19." The Lancet Respiratory Medicine 8, no. 4 (2020): e20. Doi: https://doi.org/10.1016/S2213-2600(20)30117-X

Cao Y, Li L, Feng Z, Wan S, Huang P, Sun X, Wen F, Huang X, Ning G, Wang W. "Comparative genetic analysis of the novel coronavirus (2019-nCoV/SARS-CoV-2) receptor ACE2 in different populations." Cell Discovery 6, no. 1 (2020): 1-4. Doi: https://doi.org/10.1038/s41421-020-0147-1

Chen J, Lee KH, Steinhauer DA, Stevens DJ, Skehel JJ, Wiley DC. "Structure of the hemagglutinin precursor cleavage site, a determinant of influenza pathogenicity and the origin of the labile conformation." Cell 95, no. 3 (1998): 409-417. Doi: https://doi.org/10.1016/S0092-8674(00)81771-7

Chen X, Miragaia RJ, Natarajan KN, Teichmann SA. "A rapid and robust method for single cell chromatin accessibility profiling." Nature Communications9, no. 1 (2018): 1-9. Doi: https://doi.org/10.1038/s41467-018-07771-0

Crocker J, Abe N, Rinaldi L, McGregor AP, Frankel N, Wang S, Alsawadi A, Valenti P, Plaza S, Payre F, Mann RS. "Low affinity binding site clusters confer hox specificity and regulatory robustness." Cell 160, no. 1-2 (2015): 191-203. Doi: https://doi.org/10.1016/j.cell.2014.11.041

D’Amato M, Molino A, Calabrese G, Cecchi L, Annesi-Maesano I, D’Amato G. "The impact of cold on the respiratory tract and its consequences to respiratory health." Clinical and translational allergy 8, no. 1 (2018): 20. Doi: https://doi.org/10.1186/s40413-015-0073-0

Damle B, Vourvahis M, Wang E, Leaney J, Corrigan B. "Clinical Pharmacology Perspectives on the Antiviral Activity of Azithromycin and Use in COVID-19." Clinical Pharmacology \& Therapeutics (2020). Doi: https://doi.org/10.1002/cpt.1857

del Rio C, Malani PN. "COVID-19—new insights on a rapidly changing epidemic." Jama (2020). Doi: 10.1001/jama.2020.3072

Delanghe JR, Speeckaert MM, De Buyzere ML. "The host's angiotensin-converting enzyme polymorphism may explain epidemiological findings in COVID-19 infections." Clinica Chimica Acta; International Journal of Clinical Chemistry 505 (2020): 192. Doi: 10.1016/j.cca.2020.03.031

Donoghue M, Hsieh F, Baronas E, Godbout K, Gosselin M, Stagliano N, Donovan M, Woolf B, Robison K, Jeyaseelan R, Breitbart RE. "A novel angiotensin-converting enzyme-related carboxypeptidase (ACE2) converts angiotensin I to angiotensin 1-9." Circulation research 87, no. 5 (2000): e1-e9. Doi: https://doi.org/10.1161/01.RES.87.5.e1

Driggin E, Madhavan MV, Bikdeli B, Chuich T, Laracy J, Bondi-Zoccai G, Brown TS, Der Nigoghossian C, Zidar DA, Haythe J, Brodie D. "Cardiovascular considerations for patients, health care workers, and health systems during the coronavirus disease 2019 (COVID-19) pandemic." Journal of the American College of Cardiology (2020). Doi: https://doi.org/10.1016/j.jacc.2020.03.031 
Fagerberg L, Hallström BM, Oksvold P, Kampf C, Djureinovic D, Odeberg J, Habuka M, Tahmasebpoor S, Danielsson A, Edlund K, Asplund A. "Analysis of the human tissue-specific expression by genome-wide integration of transcriptomics and antibody-based proteomics." Molecular \& Cellular Proteomics 13, no. 2 (2014): 397-406. Doi: 10.1074/mcp.M113.035600

Ferrario CM, Jessup J, Chappell MC, Averill DB, Brosnihan KB, Tallant EA, Diz DI, Gallagher PE. "Effect of angiotensin-converting enzyme inhibition and angiotensin II receptor blockers on cardiac angiotensin-converting enzyme 2." Circulation 111, no. 20 (2005): 2605 2610. Doi: https://doi.org/10.1161/CIRCULATIONAHA.104.510461

Gautret P, Lagier JC, Parola P, Meddeb L, Mailhe M, Doudier B, Courjon J, Giordanengo V, Vieira VE, Dupont HT, Honoré S. "Hydroxychloroquine and azithromycin as a treatment of COVID-19: results of an open-label non-randomized clinical trial." International journal of antimicrobial agents (2020): 105949. Doi: https://doi.org/10.1016/j.ijantimicag.2020.105949

Giacomelli A, Pezzati L, Conti F, Bernacchia D, Siano M, Oreni L, Rusconi S, Gervasoni C, Ridolfo AL, Rizzardini G, Antinori S. "Self-reported olfactory and taste disorders in SARS-CoV-2 patients: a cross-sectional study." Clin Infect Dis 70 (2020). Doi: https://doi.org/10.1093/cid/ciaa330

Gielen V, Johnston SL, Edwards MR. "Azithromycin induces anti-viral responses in bronchial epithelial cells." European Respiratory Journal 36, no. 3 (2010): 646-654. Doi: 10.1183/09031936.00095809

Guan WJ, Liang WH, Zhao Y, Liang HR, Chen ZS, Li YM, Liu XQ, Chen RC, Tang CL, Wang T, Ou CQ. "Comorbidity and its impact on 1590 patients with Covid-19 in China: A Nationwide Analysis." European Respiratory Journal (2020). Doi: 10.1183/13993003.00547-202

Guan WJ, Ni ZY, Hu Y, Liang WH, Ou CQ, He JX, Liu L, Shan H, Lei CL, Hui DS, Du B. "China Medical Treatment Expert Group for Covid-19." Clinical characteristics of coronavirus disease (2019). Doi: 10.1056/NEJMoa2002032

Hauser A, Counotte MJ, Margossian CC, Konstantinoudis G, Low N, Althaus CL, Riou J. "Estimation of SARS-CoV-2 mortality during the early stages of an epidemic: a modelling study in Hubei, China and northern Italy." medRxiv (2020). Doi: https://doi.org/10.1101/2020.03.04.20031104

Hikmet F, Mear L, Uhlen M, Lindskog C. Hikmet, Feria, Loren Mear, Mathias Uhlen, and Cecilia Lindskog. "The protein expression profile of ACE2 in human tissues." bioRxiv (2020). Doi: https://doi.org/10.1101/2020.03.31.016048

Hoffmann M, Kleine-Weber H, Schroeder S, Krüger N, Herrler T, Erichsen S, Schiergens TS, Herrler G, Wu NH, Nitsche A, Müller MA. "SARS-CoV-2 cell entry depends on ACE2 and TMPRSS2 and is blocked by a clinically proven protease inhibitor." Cell (2020). Doi: https://doi.org/10.1016/j.cell.2020.02.052

Huang ML, Li X, Meng Y, Xiao B, Ma Q, Ying SS, Wu PS, Zhang ZS. "Upregulation of angiotensinconverting enzyme (ACE) 2 in hepatic fibrosis by ACE inhibitors." Clinical and Experimental Pharmacology and Physiology 37, no. 1 (2010): e1-e6. Doi: https://doi.org/10.1111/j.14401681.2009.05302.x

Kain KC, Shanks GD, Keystone JS. "Malaria chemoprophylaxis in the age of drug resistance. I. Currently recommended drug regimens." Clinical infectious diseases 33, no. 2 (2001): 226-234. Doi: https://doi.org/10.1086/321817

Kim MS, Pinto SM, Getnet D, Nirujogi RS, Manda SS, Chaerkady R, Madugundu AK, Kelkar DS, Isserlin R, Jain S, Thomas JK. "A draft map of the human proteome." Nature 509, no. 7502 (2014): 575-581. Doi: https://doi.org/10.1038/nature13302 
Kwok KO, Lai F, Wei WI, Wong SY, Tang JW. "Herd immunity-estimating the level required to halt the COVID-19 epidemics in affected countries." Journal of Infection (2020). Doi: https://doi.org/10.1016/j.jinf.2020.03.027

Kwok YL, Gralton J, McLaws ML. "Face touching: A frequent habit that has implications for hand hygiene." American journal of infection control 43, no. 2 (2015): 112-114. Doi: https://doi.org/10.1016/j.ajic.2014.10.015

Li G, De Clercq E. "Therapeutic options for the 2019 novel coronavirus (2019-nCoV)." (2020): 149150. Doi: 10.1038/d41573-020-00016-0

Liu J, Cao R, Xu M, Wang X, Zhang H, Hu H, Li Y, Hu Z, Zhong W, Wang M. "Hydroxychloroquine, a less toxic derivative of chloroquine, is effective in inhibiting SARS-CoV-2 infection in vitro." Cell discovery 6, no. 1 (2020): 1-4. Doi: https://doi.org/10.1038/s41421-020-0156-0

Lu R, Zhao X, Li J, Niu P, Yang B, Wu H, Wang W, Song H, Huang B, Zhu N, Bi Y. "Genomic characterisation and epidemiology of 2019 novel coronavirus: implications for virus origins and receptor binding." The Lancet 395, no. 10224 (2020): 565-574. Doi: https://doi.org/10.1016/S01406736(20)30251-8

Lu X, Zhang L, Du H, Zhang J, Li YY, Qu J, Zhang W, Wang Y, Bao S, Li Y, Wu C. "SARS-CoV-2 infection in children." New England Journal of Medicine (2020). Doi: 10.1056/NEJMc2005073

Lukassen S, Chua RL, Trefzer T, Kahn NC, Schneider MA, Muley T, Winter H, Meister M, Veith C, Boots AW, Hennig BP. "SARS-CoV-2 receptor ACE2 and TMPRSS2 are predominantly expressed in a transient secretory cell type in subsegmental bronchial branches." bioRxiv (2020). Doi: https://doi.org/10.1101/2020.03.13.991455

Ma J. "Coronavirus: China's first confirmed Covid-19 case traced back to November 17." South China Morning Post13 (2020)

Muramatsu T. "Basigin: a multifunctional membrane protein with an emerging role in infections by malaria parasites." Expert opinion on therapeutic targets 16, no. 10 (2012): 999-1011. Doi: $10.1517 / 14728222.2012 .711818$

Muus C, Luecken MD, Eraslan G, Waghray A, Heimberg G, Sikkema L, Kobayashi Y, Vaishnav ED, Subramanian A, Smillie C, Jagadeesh K. "Integrated analyses of single-cell atlases reveal age, gender, and smoking status associations with cell type-specific expression of mediators of SARS-CoV-2 viral entry and highlights inflammatory programs in putative target cells." BioRxiv (2020). Doi: https://doi.org/10.1101/2020.04.19.049254.

Oliveira-Paula GH, Pereira SC, Tanus-Santos JE, Lacchini R. Oliveira-Paula, Gustavo H., Sherliane C. Pereira, Jose E. Tanus-Santos, and Riccardo Lacchini. "Pharmacogenomics And Hypertension: Current Insights." Pharmacogenomics and Personalized Medicine 12 (2019): 341. Doi: 10.2147/PGPM.S230201

Qi F, Qian S, Zhang S, Zhang Z. "Single cell RNA sequencing of 13 human tissues identify cell types and receptors of human coronaviruses." Biochemical and biophysical research communications (2020). Doi: https://doi.org/10.1016/j.bbrc.2020.03.044

Rayner CR, Smith PF, Hershberger K, Wesche D. "Optimizing COVID-19 candidate therapeutics: Thinking Without Borders." Clinical and Translational Science (2020). Doi: https://doi.org/10.1111/cts.12790 
Re RN. "Mechanisms of disease: local renin-angiotensin-aldosterone systems and the pathogenesis and treatment of cardiovascular disease." Nature Clinical Practice Cardiovascular Medicine 1, no. 1 (2004): 42-47. Doi: https://doi.org/10.1038/ncpcardio0012

Rothe C, Schunk M, Sothmann P, Bretzel G, Froeschl G, Wallrauch C, Zimmer T, Thiel V, Janke C, Guggemos W, Seilmaier M. "Transmission of 2019-nCoV infection from an asymptomatic contact in Germany." New England Journal of Medicine 382, no. 10 (2020): 970-971. Doi: https://doi.org/10.1056/NEJMc2001468

Schmidt T, Samaras P, Frejno M, Gessulat S, Barnert M, Kienegger H, Krcmar H, Schlegl J, Ehrlich HC, Aiche S, Kuster B. "ProteomicsDB." Nucleic acids research 46, no. D1 (2018): D1271-D1281. Doi: https://doi.org/10.1093/nar/gkz974

Stawiski EW, Diwanji D, Suryamohan K, Gupta R, Fellouse FA, Sathirapongsasuti F, Liu J, Jiang YP, Ratan A, Mis M, Santhosh D. "Human ACE2 receptor polymorphisms predict SARS-CoV-2 susceptibility." bioRxiv (2020). Doi: https://doi.org/10.1101/2020.04.07.024752

Sungnak W, Huang N, Bécavin C, Berg M, Network HC. "SARS-CoV-2 Entry Genes Are Most Highly Expressed in Nasal Goblet and Ciliated Cells within Human Airways." arXiv preprint arXiv:2003.06122 (2020). Doi: 10.1038/s41591-020-0868-6

Tipnis SR, Hooper NM, Hyde R, Karran E, Christie G, Turner AJ. "A human homolog of angiotensinconverting enzyme cloning and functional expression as a captopril-insensitive carboxypeptidase." Journal of Biological Chemistry 275, no. 43 (2000): 33238-33243. Doi: 10.1074/jbc.M002615200

Tran DH, Sugamata R, Hirose T, Suzuki S, Noguchi Y, Sugawara A, Ito F, Yamamoto T, Kawachi S, Akagawa KS, Ōmura S. "Azithromycin, a 15-membered macrolide antibiotic, inhibits influenza A (H1N1) pdm09 virus infection by interfering with virus internalization process." The Journal of antibiotics 72, no. 10 (2019): 759-768. Doi: https://doi.org/10.1038/s41429-019-0204-x

Turner AJ. "ACE2 Cell Biology, Regulation, and Physiological Functions." The Protective Arm of the Renin Angiotensin System (RAS) (2015): 185. Doi:10.1016/B978-0-12-801364-9.00025-0. ISBN 9780-12-801364-9

Ulrich H, Pillat MM. "CD147 as a Target for COVID-19 Treatment: Suggested Effects of Azithromycin and Stem Cell Engagement." Stem Cell Reviews and Reports (2020): 1-7. Doi: 10.1007/s12015-02009976-7

Ussher JR, Lopaschuk GD. "An ACE up your sleeve: 2 is better than 1." (2012): 1270-1272. Doi: 10.1161/circresaha.112.269951

Vardavas CI, Nikitara K. "COVID-19 and smoking: A systematic review of the evidence." Tobacco induced diseases 18 (2020). Doi: 10.18332/tid/119324

Walls AC, Park YJ, Tortorici MA, Wall A, McGuire AT, Veesler D. "Structure, function, and antigenicity of the SARS-CoV-2 spike glycoprotein." Cell (2020). Doi: https://doi.org/10.1016/j.cell.2020.02.058

Wan Y, Shang J, Graham R, Baric RS, Li F. "Receptor recognition by the novel coronavirus from Wuhan: an analysis based on decade-long structural studies of SARS coronavirus." Journal of virology 94, no. 7 (2020). Doi: 10.1128/jvi.00127-20

Wang C, Liu L, Hao X, Guo H, Wang Q, Huang J, He N, Yu H, Lin X, Pan A, Wei S. "Evolving epidemiology and impact of non-pharmaceutical interventions on the outbreak of coronavirus disease 2019 in Wuhan, China." medRxiv (2020). Doi: https://doi.org/10.1101/2020.03.03.20030593 
Wilhelm M, Schlegl J, Hahne H, Gholami AM, Lieberenz M, Savitski MM, Ziegler E, Butzmann L, Gessulat S, Marx H, Mathieson T. "Mass-spectrometry-based draft of the human proteome." Nature 509, no. 7502 (2014): 582-587. Doi: https://doi.org/10.1038/nature13319

World Health Organization. "World malaria report 2019." (2019). ISBN 978-92-4-156572-1: xii-xiii, $4-10$

Wrapp D, Wang N, Corbett KS, Goldsmith JA, Hsieh CL, Abiona O, Graham BS, McLellan JS. "CryoEM structure of the 2019-nCoV spike in the prefusion conformation." Science 367, no. 6483 (2020): 1260-1263. Doi: https://doi.org/10.1126/science.abb2507

$\mathrm{Wu} \mathrm{Z}$, McGoogan JM. "Characteristics of and important lessons from the coronavirus disease 2019 (COVID-19) outbreak in China: summary of a report of 72314 cases from the Chinese Center for Disease Control and Prevention." Jama (2020). Doi: :10.1001/jama.2020.2648

Wu F, Zhao S, Yu B, Chen YM, Wang W, Song ZG, Hu Y, Tao ZW, Tian JH, Pei YY, Yuan ML. "A new coronavirus associated with human respiratory disease in China." Nature 579, no. 7798 (2020): 265-269. Doi: https://doi.org/10.1038/s41586-020-2008-3

Xia J, Tong J, Liu M, Shen Y, Guo D. "Evaluation of coronavirus in tears and conjunctival secretions of patients with SARS-CoV-2 infection." Journal of medical virology (2020). Doi: 10.1002/jmv.25725

Xu H, Zhong L, Deng J, Peng J, Dan H, Zeng X, Li T, Chen Q. "High expression of ACE2 receptor of 2019-nCoV on the epithelial cells of oral mucosa." International Journal of Oral Science 12, no. 1 (2020): 1-5. Doi: https://doi.org/10.1038/s41368-020-0074-x

Yang J, Zheng Y, Gou X, Pu K, Chen Z, Guo Q, Ji R, Wang H, Wang Y, Zhou Y. "Prevalence of comorbidities in the novel Wuhan coronavirus (COVID-19) infection: a systematic review and metaanalysis." International Journal of Infectious Diseases (2020). Doi: https://doi.org/10.1016/j.ijid.2020.03.017

Zhao Y, Zhao Z, Wang Y, Zhou Y, Ma Y, Zuo W. "Single-cell RNA expression profiling of ACE2, the putative receptor of Wuhan 2019-nCov." BioRxiv (2020). Doi: https://doi.org/10.1101/2020.01.26.919985

Zheng YY, Ma YT, Zhang JY, Xie X. "COVID-19 and the cardiovascular system." Nature Reviews Cardiology 17, no. 5 (2020): 259-260. Doi: https://doi.org/10.1038/s41569-020-0360-5

Zou X, Chen K, Zou J, Han P, Hao J, Han Z. "Single-cell RNA-seq data analysis on the receptor ACE2 expression reveals the potential risk of different human organs vulnerable to 2019-nCoV infection." Frontiers of medicine (2020): 1-8. Doi: https://doi.org/10.1007/s11684-020-0754-0 
Tables and Figures

Table 1. COVID-19 infections in the East Asian countries (April 29, 2020)

\begin{tabular}{|l|l|l|l|l|l|l|l|l|}
\hline & Total & Death & IDR (\%) & $\begin{array}{l}\text { Recovered } \\
\text { cases }\end{array}$ & $\begin{array}{l}\text { Recovered } \\
\text { cases (\%) }\end{array}$ & $\begin{array}{l}\text { Active } \\
\text { cases }\end{array}$ & $\begin{array}{l}\text { Closed } \\
\text { cases } \\
\text { cases } \\
\text { (\%) }\end{array}$ \\
\hline Japan & 13,736 & 394 & 17.18 & 1,899 & 82.82 & 11,443 & 2,293 & 16.69 \\
\hline China & 82,858 & 4,633 & 5.64 & 77,578 & 94.36 & 647 & 82,211 & 99.22 \\
\hline $\begin{array}{l}\text { South } \\
\text { Korea }\end{array}$ & 10,761 & 246 & 2.68 & 8,922 & 97.32 & 1,593 & 9,168 & 85.20 \\
\hline Malaysia & 5,851 & 100 & 2.42 & 4,032 & 97.58 & 1,719 & 4,132 & 70.62 \\
\hline Thailand & 2,938 & 54 & 2.00 & 2,652 & 98.00 & 232 & 2,706 & 92.10 \\
\hline Taiwan & 429 & 6 & 1.92 & 307 & 98.08 & 116 & 313 & 72.96 \\
\hline Singapore & 14,951 & 14 & 1.23 & 1,128 & 98.77 & 13,809 & 1,142 & 7.64 \\
\hline Hong Kong & 1,038 & 4 & 0.49 & 811 & 99.51 & 223 & 815 & 78.52 \\
\hline Vietnam & 270 & & 0.00 & 222 & 100.00 & 48 & 222 & 82.22 \\
\hline
\end{tabular}

Various countries with COVID-19 infections are sorted in descending order of their Interim Death Rates (\%). Based on the IDRs various countries are grouped into two groups: $11-24 \%$ IDRs, greenish yellow; and below 10\% IDRs, green.

‡Updated data was obtained from https://www.worldometers.info/coronavirus/. 
Table 2. COVID-19 infections in the Middle East countries (April 29, 2020)

\begin{tabular}{|l|l|l|l|l|l|l|l|l|}
\hline & Total & Death & $\begin{array}{l}\text { IDR } \\
\text { (\%) }\end{array}$ & $\begin{array}{l}\text { Recovered } \\
\text { cases }\end{array}$ & $\begin{array}{l}\text { Recovered } \\
\text { cases (\%) }\end{array}$ & $\begin{array}{l}\text { Active } \\
\text { cases }\end{array}$ & $\begin{array}{l}\text { Closed } \\
\text { cases }\end{array}$ & $\begin{array}{l}\text { cases } \\
\text { (\%) }\end{array}$ \\
\hline Iran & 92,584 & 5,877 & 7.50 & 72,439 & 92.50 & 14,268 & 78,316 & 84.59 \\
\hline Iraq & 1,928 & 90 & 6.39 & 1,319 & 93.61 & 519 & 1,409 & 73.08 \\
\hline $\begin{array}{l}\text { Saudi } \\
\text { Arabia }\end{array}$ & 20,077 & 152 & 5.18 & 2,784 & 94.82 & 17,141 & 2,936 & 14.62 \\
\hline UAE & 11,380 & 89 & 3.92 & 2,181 & 96.08 & 9,110 & 2,270 & 19.95 \\
\hline Palestine & 343 & 2 & 2.74 & 71 & 97.26 & 270 & 73 & 21.28 \\
\hline Oman & 2,131 & 10 & 2.67 & 364 & 97.33 & 1,757 & 374 & 17.55 \\
\hline Israel & 15,728 & 210 & 2.64 & 7,746 & 97.36 & 7,772 & 7,956 & 50.58 \\
\hline Jordan & 449 & 8 & 2.25 & 348 & 97.75 & 93 & 356 & 79.29 \\
\hline Kuwait & 3,440 & 23 & 1.92 & 1,176 & 98.08 & 2,241 & 1,199 & 34.85 \\
\hline Qatar & 11,921 & 10 & 0.87 & 1,134 & 99.13 & 10,777 & 1,144 & 9.60 \\
\hline Bahrain & 2,811 & 8 & 0.61 & 1,310 & 99.39 & 1,493 & 1,318 & 46.89 \\
\hline
\end{tabular}

Various countries with COVID-19 infections are sorted in descending order of their Interim Death Rates (\%). Based on the IDRs all countries are grouped in one group of below $10 \%$ IDRs, green.

‡Updated data was obtained from https://www.worldometers.info/coronavirus/. 
Table 3. COVID-19 infections in the Western Europe (April 29, 2020)

\begin{tabular}{|l|l|l|l|l|l|l|l|l|}
\hline & Total & Death & $\begin{array}{l}\text { IDR } \\
\text { (\%) }\end{array}$ & $\begin{array}{l}\text { Recovered } \\
\text { cases }\end{array}$ & $\begin{array}{l}\text { Recovered } \\
\text { cases (\%) }\end{array}$ & $\begin{array}{l}\text { Active } \\
\text { cases }\end{array}$ & $\begin{array}{l}\text { Closed } \\
\text { cases }\end{array}$ & $\begin{array}{l}\text { cases } \\
\text { (\%) }\end{array}$ \\
\hline UK & 161,145 & 21,678 & 98.44 & 344 & 1.56 & 139,123 & 22,022 & 13.67 \\
\hline Netherlands & 38,416 & 4,566 & 94.81 & 250 & 5.19 & 33,600 & 4,816 & 12.54 \\
\hline Norway & 7,660 & 206 & 86.55 & 32 & 13.45 & 7,422 & 238 & 3.11 \\
\hline Sweden & 19,621 & 2,355 & 70.09 & 1,005 & 29.91 & 16,261 & 3,360 & 17.12 \\
\hline Portugal & 24,322 & 948 & 40.56 & 1,389 & 59.44 & 21,985 & 2,337 & 9.61 \\
\hline Belgium & 47,334 & 7,331 & 40.12 & 10,943 & 59.88 & 29,060 & 18,274 & 38.61 \\
\hline France & 165,911 & 23,660 & 33.54 & 46,886 & 66.46 & 95,365 & 70,546 & 42.52 \\
\hline Italy & 201,505 & 27,359 & 28.41 & 68,941 & 71.59 & 105,205 & 96,300 & 47.79 \\
\hline Spain & 232,128 & 23,822 & 16.13 & 123,903 & 83.87 & 84,403 & 147,725 & 63.64 \\
\hline Ireland & 19,877 & 1,159 & 11.15 & 9,233 & 88.85 & 9,485 & 10,392 & 52.28 \\
\hline Switzerland & 29,264 & 1,699 & 6.99 & 22,600 & 93.01 & 4,965 & 24,299 & 83.03 \\
\hline Finland & 4,740 & 199 & 6.64 & 2,800 & 93.36 & 1,741 & 2,999 & 63.27 \\
\hline Denmark & 8,851 & 434 & 6.62 & 6,121 & 93.38 & 2,296 & 6,555 & 74.06 \\
\hline Germany & 159,912 & 6,314 & 5.10 & 117,400 & 94.90 & 36,198 & 123,714 & 77.36 \\
\hline Austria & 15,357 & 569 & 4.33 & 12,580 & 95.67 & 2,208 & 13,149 & 85.62 \\
\hline Iceland & 1,795 & 10 & 0.61 & 1,636 & 99.39 & 149 & 1,646 & 91.70 \\
\hline
\end{tabular}

Various countries with COVID-19 infections are sorted in descending order of their Interim Death Rates (\%). Based on the IDRs various countries are grouped into five groups: higher than $80 \%$ IDRs, red; $51-79 \%$ IDRs, brown; $25-50 \%$ IDRs, dark yellow; 11-24\% IDRs, greenish yellow; and below $10 \%$ IDRs, green.

‡Updated data was obtained from https://www.worldometers.info/coronavirus/. 
Table 4. COVID-19 infections in the US (April 17, 2020)

\begin{tabular}{|c|c|c|c|c|c|c|c|c|c|}
\hline & Total & Death & $\begin{array}{l}\text { IDR } \\
\text { (\%) }\end{array}$ & $\begin{array}{l}\text { Recovered } \\
\text { cases }\end{array}$ & $\begin{array}{l}\text { Recovered } \\
\text { cases (\%) }\end{array}$ & $\begin{array}{l}\text { Active } \\
\text { cases }\end{array}$ & $\begin{array}{l}\text { Closed } \\
\text { cases }\end{array}$ & $\begin{array}{l}\text { Closed } \\
\text { cases } \\
(\%)\end{array}$ & $\begin{array}{c}\text { German } \\
\text { Ancestry* }\end{array}$ \\
\hline USA & $1,035,765$ & 59,266 & 29.41 & 142,238 & 70.59 & 834,261 & 201,504 & 19.45 & \\
\hline \multicolumn{10}{|l|}{ States } \\
\hline Mississippi & 6,342 & 239 & 100.00 & 0 & 0.00 & 6,103 & 239 & 3.77 & 5.3 \\
\hline Oregon & 2,385 & 99 & 100.00 & 0 & 0.00 & 2,286 & 99 & 4.15 & 19.1 \\
\hline Vermont & 862 & 47 & 100.00 & 0 & 0.00 & 815 & 47 & 5.45 & 10.5 \\
\hline Indiana & 16,588 & 992 & 98.61 & 14 & 1.39 & 15,582 & 1,006 & 6.06 & 23.0 \\
\hline Georgia & 24,854 & 1,036 & 97.09 & 31 & 2.91 & 23,787 & 1,067 & 4.29 & 7.0 \\
\hline Connecticut & 26,312 & 2,089 & 96.98 & 65 & 3.02 & 24,158 & 2,154 & 8.19 & 9.0 \\
\hline Alabama & 6,750 & 242 & 92.37 & 20 & 7.63 & 6,488 & 262 & 3.88 & 6.8 \\
\hline Ohio & 16,769 & 799 & 86.94 & 120 & 13.06 & 15,850 & 919 & 5.48 & 25.6 \\
\hline New Jersey & 113,856 & 6,442 & 83.52 & 1,271 & 16.48 & 106,143 & 7,713 & 6.77 & 10.6 \\
\hline Arizona & 6,948 & 293 & 80.72 & 70 & 19.28 & 6,585 & 363 & 5.22 & 13.7 \\
\hline Illinois & 48,102 & 2,125 & 77.81 & 606 & 22.19 & 45,371 & 2,731 & 5.68 & 18.6 \\
\hline Pennsylvania & 45,016 & 2,060 & 72.92 & 765 & 27.08 & 42,191 & 2,825 & 6.28 & 25.1 \\
\hline Nebraska & 3,374 & 55 & 71.43 & 22 & 28.57 & 3,297 & 77 & 2.28 & 36.1 \\
\hline Florida & 32,846 & 1,171 & 63.06 & 686 & 36.94 & 30,989 & 1,857 & 5.65 & 10.0 \\
\hline Colorado & 14,316 & 736 & 56.83 & 559 & 43.17 & 13,021 & 1,295 & 9.05 & 20.3 \\
\hline Maryland & 20,113 & 1,016 & 44.58 & 1,263 & 55.42 & 17,834 & 2,279 & 11.33 & 13.8 \\
\hline Rhode Island & 7,926 & 239 & 41.14 & 342 & 58.86 & 7,345 & 581 & 7.33 & 5.4 \\
\hline Missouri & 7,376 & 327 & 37.41 & 547 & 62.59 & 6,502 & 874 & 11.85 & 24.2 \\
\hline California & 46,163 & 1,862 & 35.81 & 3,337 & 64.19 & 40,964 & 5,199 & 11.26 & 8.1 \\
\hline New York & 301,450 & 23,144 & 33.01 & 46,963 & 66.99 & 231,343 & 70,107 & 23.26 & 11.1 \\
\hline Michigan & 39,262 & 3,567 & 29.95 & 8,342 & 70.05 & 27,353 & 11,909 & 30.33 & 20.3 \\
\hline Washington & 13,842 & 786 & 29.81 & 1,851 & 70.19 & 11,205 & 2,637 & 19.05 & 17.8 \\
\hline Massachusetts & 58,302 & 3,153 & 27.97 & 8,118 & 72.03 & 47,031 & 11,271 & 19.33 & 6.0 \\
\hline $\begin{array}{l}\text { District of } \\
\text { Columbia }\end{array}$ & 3,994 & 190 & 22.35 & 660 & 77.65 & 3,144 & 850 & 21.28 & ND \\
\hline
\end{tabular}




\begin{tabular}{|c|c|c|c|c|c|c|c|c|c|}
\hline North Carolina & 9,739 & 361 & 21.71 & 1,302 & 78.29 & 8,076 & 1,663 & 17.08 & 10.4 \\
\hline Virginia & 14,339 & 492 & 21.33 & 1,815 & 78.67 & 12,032 & 2,307 & 16.09 & 11.5 \\
\hline Kansas & 3,577 & 127 & 20.16 & 503 & 79.84 & 2,947 & 630 & 17.61 & 27.2 \\
\hline Kentucky & 4,375 & 225 & 16.70 & 1,122 & 83.30 & 3,028 & 1,347 & 30.79 & 14.4 \\
\hline Minnesota & 4,181 & 301 & 13.60 & 1,912 & 86.40 & 1,968 & 2,213 & 52.93 & 33.8 \\
\hline New Mexico & 2,974 & 110 & 13.50 & 705 & 86.50 & 2,159 & 815 & 27.40 & 8.8 \\
\hline Wisconsin & 6,289 & 300 & 11.48 & 2,313 & 88.52 & 3,676 & 2,613 & 41.55 & 40.5 \\
\hline Delaware & 4,575 & 137 & 11.11 & 1,096 & 88.89 & 3,342 & 1,233 & 26.95 & 13.5 \\
\hline Louisiana & 27,286 & 1,801 & 9.43 & 17,303 & 90.57 & 8,182 & 19,104 & 70.01 & 7.5 \\
\hline Oklahoma & 3,410 & 207 & 8.39 & 2,260 & 91.61 & 943 & 2,467 & 72.35 & 13.7 \\
\hline Maine & 1,040 & 51 & 8.02 & 585 & 91.98 & 404 & 636 & 61.15 & 8.1 \\
\hline Nevada & 4,805 & 225 & 7.83 & 2,647 & 92.17 & 1,933 & 2,872 & 59.77 & 11.3 \\
\hline West Virginia & 1,095 & 38 & 7.32 & 481 & 92.68 & 576 & 519 & 47.40 & 17.6 \\
\hline $\begin{array}{l}\text { New } \\
\text { Hampshire }\end{array}$ & 2,010 & 60 & 6.02 & 936 & 93.98 & 1,014 & 996 & 49.55 & 9.0 \\
\hline lowa & 6,376 & 136 & 5.91 & 2,164 & 94.09 & 4,076 & 2,300 & 36.07 & 35.1 \\
\hline Texas & 26,171 & 690 & 5.82 & 11,170 & 94.18 & 14,311 & 11,860 & 45.32 & 9.6 \\
\hline Idaho & 1,952 & 60 & 5.23 & 1,087 & 94.77 & 805 & 1,147 & 58.76 & 17.5 \\
\hline South Carolina & 5,735 & 192 & 4.93 & 3,701 & 95.07 & 1,842 & 3,893 & 67.88 & 10.0 \\
\hline Utah & 4,343 & 45 & 4.82 & 888 & 95.18 & 3,410 & 933 & 21.48 & 11.2 \\
\hline Arkansas & 3,127 & 57 & 4.48 & 1,216 & 95.52 & 1,854 & 1,273 & 40.71 & 10.7 \\
\hline North Dakota & 991 & 19 & 4.44 & 409 & 95.56 & 563 & 428 & 43.19 & 41.4 \\
\hline Montana & 451 & 15 & 4.04 & 356 & 95.96 & 80 & 371 & 82.26 & 26.0 \\
\hline Alaska & 351 & 9 & 3.80 & 228 & 96.20 & 114 & 237 & 67.52 & 15.6 \\
\hline Tennessee & 10,052 & 188 & 3.68 & 4,921 & 96.32 & 4,943 & 5,109 & 50.83 & 9.7 \\
\hline Hawaii & 609 & 16 & 3.07 & 505 & 96.93 & 88 & 521 & 85.55 & 5.9 \\
\hline Wyoming & 536 & 7 & 2.00 & 343 & 98.00 & 186 & 350 & 65.30 & 23.6 \\
\hline South Dakota & 2,313 & 11 & 0.78 & 1,392 & 99.22 & 910 & 1,403 & 60.66 & 38.8 \\
\hline
\end{tabular}

Various US states with COVID-19 infections in descending order of their Interim Death Rates (\%). Based on the IDRs various states are grouped into five groups: higher than $80 \%$ IDRs, 
red; $51-79 \%$ IDRs, brown; $25-50 \%$ IDRs, dark yellow; $11-24 \%$ IDRs, greenish yellow; and below $10 \%$ IDRs, green.

‡Updated data was obtained from https://www.worldometers.info/coronavirus/.

*The data on German and East Asian (not shown) ancestry of population in various US states were obtained from https://statisticalatlas.com/state/STATE/Ancestry. 


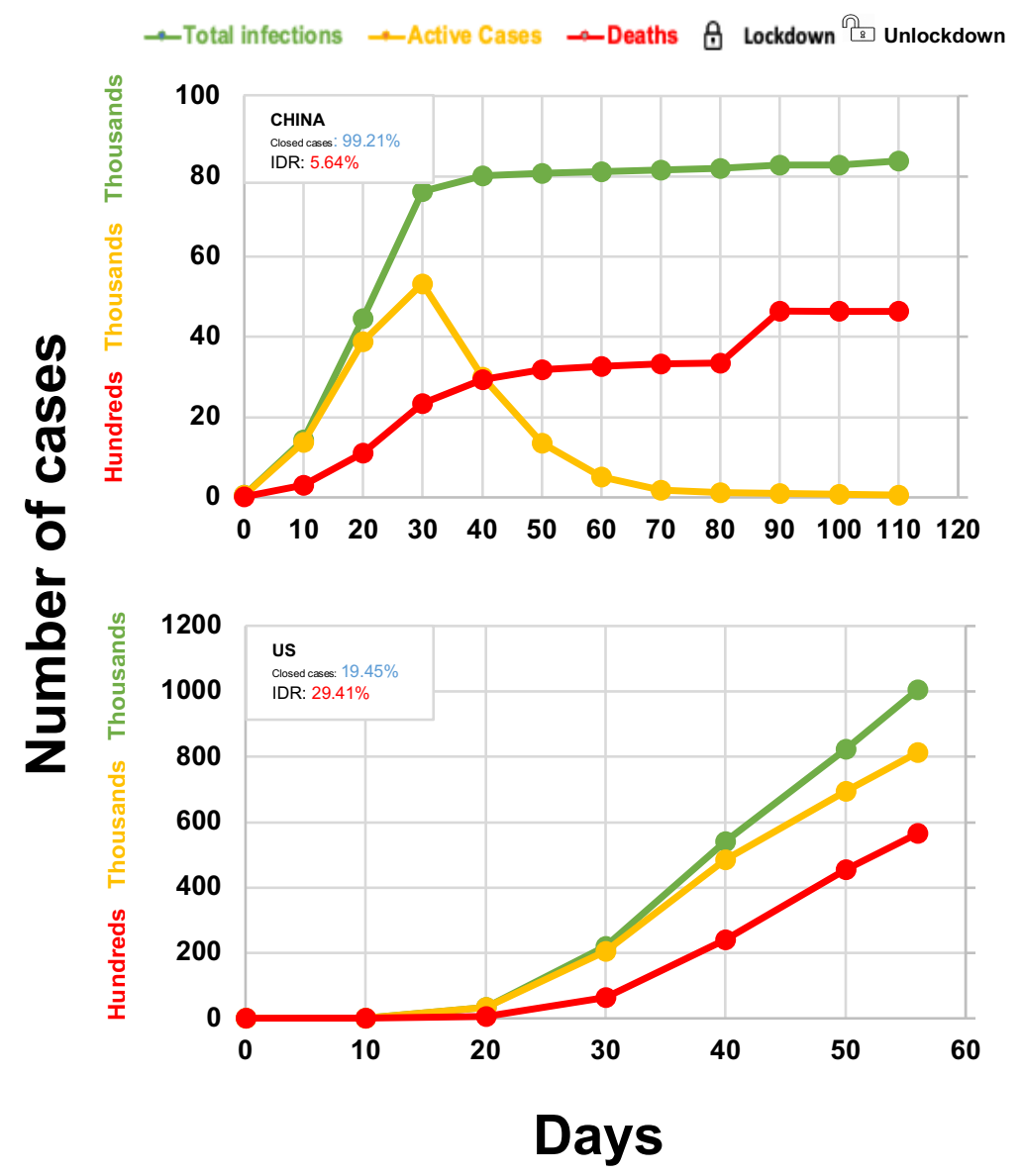

Figure 1. Impact of COVID-19 infections in China and the US ${ }^{\ddagger}$.

The day when the number of total cases reached 100 was considered as Day 0 抽ata was obtained from https://www.worldometers.info/coronavirus/. 
+Total infections +Active Cases -Deaths B Lockdown
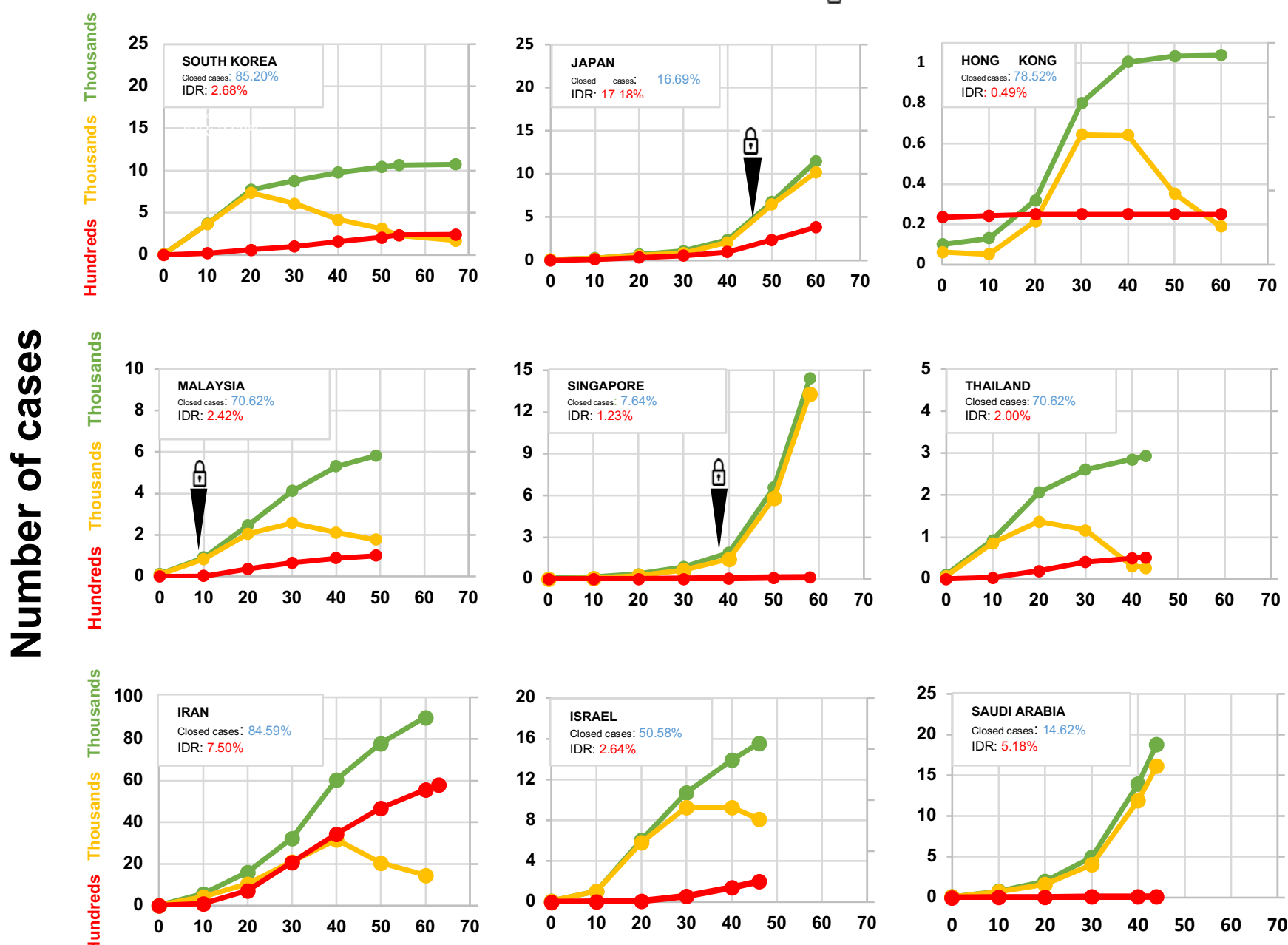

Days

Figure 2. Impact of COVID-19 infections in East Asian countries and Middle East countries $\ddagger$.

The day when the number of total cases reached 100 was considered as Day 0 .

‡Updated data was obtained from https://www.worldometers.info/coronavirus/. 

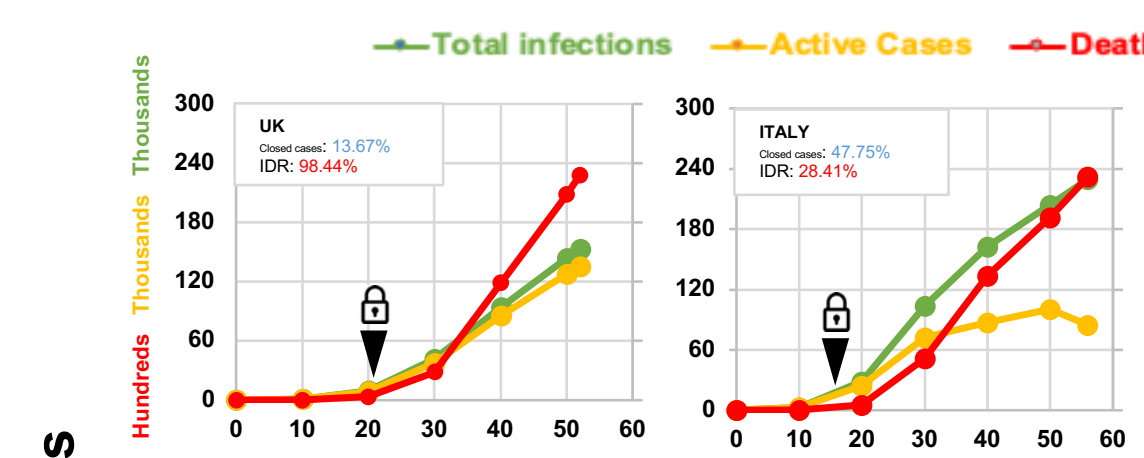

\section{(8) Lockdown}

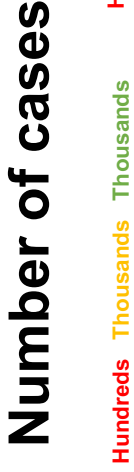
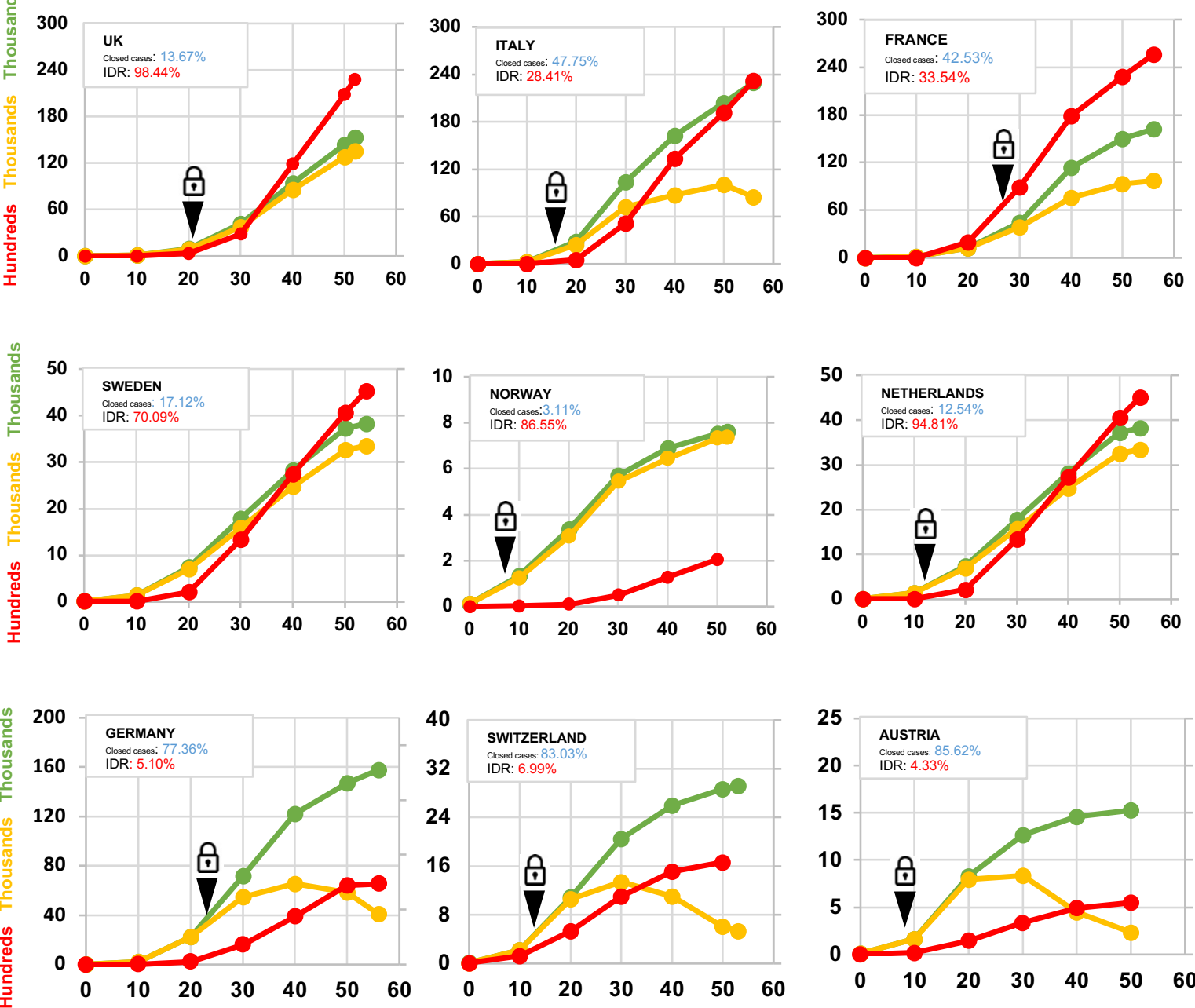

\section{Days}

\section{Figure 3. COVID-19 infections in Western European countries ${ }^{\ddagger}$}

The day when the number of total cases reached 100 was considered as Day 0 .

‡Updated data was obtained from https://www.worldometers.info/coronavirus/ 